\title{
HOURLY STABILITY ANALYSIS AS THE KEY PARAMETER OF LEAN MANUFACTURING AND LOGISTICS
}

\author{
Petr Besta \\ University of Entrepreneurship and Law, Michálkovická 1810, 71000 Ostrava, Czech Republic, petr.besta@vspp.cz \\ Kamila Janovská \\ University of Entrepreneurship and Law, Michálkovická 1810, 71000 Ostrava, Czech Republic, \\ kamila.janovska@vspp.cz \\ Petr Prosický \\ VSB - Technical University of Ostrava, Ostrava, Czech Republic, EU, petr.prosicky.st@vsb.cz \\ Lukáš Hula \\ VSB - Technical University of Ostrava, Ostrava, Czech Republic, EU, lukas.hula.st@vsb.cz
}

Keywords: production, costs, logistics, price, wasting

Abstract: Lean manufacturing belongs to the basic philosophies originating in automotive industry. It was originally based on a number of elementary principles and methods. Companies from other industrial areas have also been gradually trying to apply these principles. This leads to the incorporation of other tools from various areas into this concept. The fundamental techniques of lean manufacturing include the hourly stability (output) analysis. This method can be applied in a wide variety of manufacturing fields. The aim is a stable working worker, not a worker working rapidly and with large fluctuations. Speed and sudden changes mean inaccuracy, poor quality and problems to the manufacturing companies. The research has also carried out the hourly stability analysis in a company manufacturing components for a variety of global car manufacturers. The objective of this article is to evaluate the research of hourly stability for the selected workplaces.

\section{Introduction}

Company leanness means doing only those activities that are necessary, doing them right the first time, doing them faster than the others, while spending less money [1]. The current competitive environment puts enterprises under great pressure [2], [3]. However, it is not possible to consistently build your company simply by using cost reductions. Leanness is about improving the performance of the company by producing more than the competitors in the given space, by producing higher added value than the competitors with the given number of people and equipment, by processing more orders during the given time, and by consuming less time on the individual company processes and activities [4]. It is therefore important to do exactly what the customer wants, with a minimum number of activities and at minimum costs. Being lean therefore means earning more money, earning it faster and with less effort [5]. More and more manufacturing companies realize that without fundamental changes in their processes, their existence in the near future may be at risk [6], [7].

\section{Lean manufacturing tools}

Lean manufacturing and its principles cannot be understood as a clearly defined and closed system. This philosophy allows you to apply a variety of methods and tools, and it is also possible to use very different approaches during its implementation [8]. The implementation of lean manufacturing is mostly a reaction to some kind of problem in the organization. It is often recommended during the implementation of lean manufacturing principles to use a procedure based on the initial audit of the basic parameters of lean manufacturing, where the values of the selected indicators can be determined. According to contemporary approach, lean manufacturing is a complex system that can evaluate a variety of aspects and parameters, including the indicators assessing the quality of the individual processes, the amount of downtime, but also for example the variability of the production performance [9], [10]. Lean manufacturing uses tens of tools and metrics for this purpose. The most commonly used ones are: the amount of non-conforming production, the OEE of selected workstations, the set-up times, the inventory turnover rate, the hourly stability, the continuous production time, and the $\mathrm{C} / \mathrm{T}$ of bottlenecks. Their application must, however, always be based on the specific aspects of each organization. A number of parameters which are used to assess the production leanness rely on the principles of mass production, and it is therefore very difficult to apply them for example in individual piece production [11], [12]. That is why it is always necessary to use the individual approach when applying the lean manufacturing tools. Special attention must be paid to the methods and techniques used within the scope of lean manufacturing. Originally, these techniques were applied in the production of automobiles. The application of the 
principles of lean manufacturing in other areas was also accompanied by an increasing number and scope of the applied methods [13]. There are dozens of different methods used nowadays. The most typical and frequently used ones include, for example: TPM, 5S - a system of good management, visual management, team problem solving, batch production, management of bottlenecks, and many others. The concrete use of the individual methods is again quite dependent on the character of the manufacturing organization in question.

A different nature of the production process does not allow a universal application of all the methods.

\section{Hourly stability}

The basic tools of lean manufacturing include hourly stability. This tool, in essence, shows the stability of the planned performance for each hour during a work shift. This indicator is monitored especially on a problematic production line (machine) or in a bottleneck. High fluctuations in the performance of workers may be associated with a higher degree of non-conforming production. It is important for a worker to work evenly during the work shift, thus avoiding fluctuations in performance. Generally, the reasons for the monitoring of hourly stability can be summarized as follows:

- using shorter time intervals makes it possible to effectively identify the causes of the problems (downtime due to failure to deliver material, breakdowns of machines, tools),

- process improvement,

- long-term trend monitoring,

- identification of key problems,

- comparison of the performance of more workers.

The calculation of hourly stability $H S$ can be performed using equation (1). The result is a percentage value and it represents the rate of fluctuation of real performance compared to the planned one.

Hourly stability can be calculated as:

$$
H S=\frac{T N P P Q}{T N P P} \times 100[\%]
$$

$T N P P Q$ - total number of pieces actually produced up to the planned quantity,

$T N P P$ - total number of planned pieces.

The hourly stability indicator is usually used in the mass production environment, where the range of products is not very wide. They are workplaces (operations) where the given machine has a high production cycle. The utilization in the environment of frequent changes and high product variability is very limited.

\section{Experimental part}

The conducted research also involved a study in a company manufacturing components for the automotive industry. The hourly stability was measured at the selected workplace. The measurement was carried out during 10 shifts. The results were recorded and evaluated separately for each shift. Table 1 shows a report of a work shift from 28 November. The table shows the breakdown of the individual hours, the number of pieces that are scheduled for the shift, the actual number of pieces produced, and the actual hourly amount up to the planned one. The used methodology of the hourly stability evaluation takes into account: the total actual number of pieces produced up to the planned amount and the total number of planned pieces (relation 1).

Table 1. Record of worker performance during the specified work shift

\begin{tabular}{|c|c|c|c|c|}
\hline \multicolumn{2}{|c|}{ Working hours } & \multicolumn{3}{c|}{ Actual production } \\
\hline Day & 28.11 .2015 & $\begin{array}{c}\text { Hourly plan } \\
(\mathrm{pcs})\end{array}$ & $\begin{array}{c}\text { Actual hourly } \\
\text { amount (pcs) }\end{array}$ & $\begin{array}{c}\text { Actual hourly } \\
\text { amount up to } \\
\text { planned amount }\end{array}$ \\
\hline $\begin{array}{c}\text { Number of } \\
\text { minutes }\end{array}$ & Time period & 80 & 36 & 36 \\
\hline 42 & $6.00-7.00$ & 90 & 42 & 42 \\
\hline 60 & $7.00-8.00$ & 90 & 109 & 90 \\
\hline 60 & $8.00-9.00$ & 80 & 65 & 65 \\
\hline 60 & $9.00-10.00$ & 40 & 59 & 40 \\
\hline 30 & $10.00-11.00$ & 90 & 111 & 90 \\
\hline 50 & $11.00-12.00$ & 90 & 101 & 90 \\
\hline 59 & $12.00-13.00$ & 80 & 53 & 53 \\
\hline 43 & $13.00-14.00$ & 640 & 576 & 506 \\
\hline
\end{tabular}

$H S=\frac{506}{640} \times 100=79 \%$

The hourly stability for each shift was determined on the basis of these data. The calculation of the hourly stability for 28 November is displayed within the relation (2). The value of the hourly stability in this case is $79 \%$. This value is at the limit of acceptability. It is generally acknowledged that the desirable hourly stability rate is above $80 \%$. Of course, it always depends on the specific production conditions. 


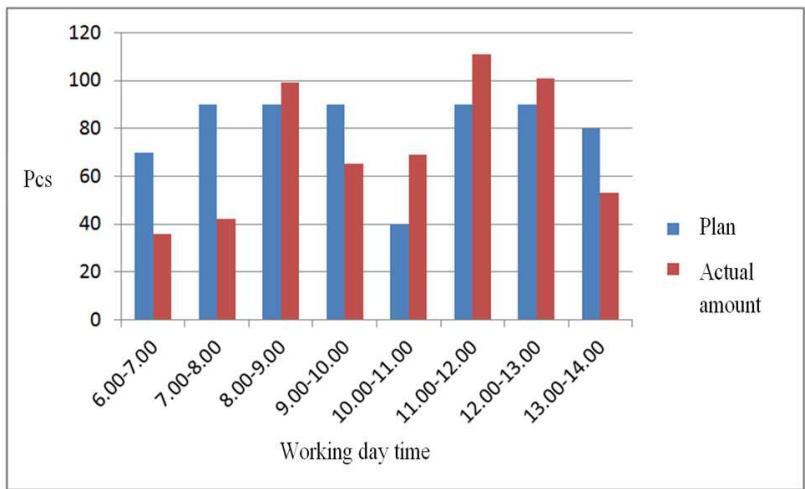

Figure 1 Comparison of the planned and actual production during 28 November 2015

Figure 1 provides a graphic illustration of the development of the planned and actual value of production using the given machine. The development clearly shows how big the difference is between the plan and the actual production. The same method was used to evaluate the hourly stability of the machine during the remaining 9 days.

Concrete values of hourly stability are presented in Table 2. The table also indicates the average hourly stability value during the monitored shift. The results show that there are significant fluctuations in the performance of the worker within the scope of the monitored machine. The value of hourly stability exceeded the required value of $80 \%$ only in a single case.

Table 2. Record of worker performance during the specified work shift

\begin{tabular}{|c|c|c|}
\hline $\begin{array}{c}\text { Measurement } \\
\text { number }\end{array}$ & Day & $\begin{array}{c}\text { Hourly stability } \\
(\%)\end{array}$ \\
\hline 1. & 28.11. & 79 \\
\hline 2. & 29.11. & 75 \\
\hline 3. & 30.11. & 81 \\
\hline 4. & 1.12. & 71 \\
\hline 5. & 2.12. & 68 \\
\hline 6. & 3.12. & 74 \\
\hline 7. & 4.12. & 72 \\
\hline 8. & 5.12. & 68 \\
\hline 9. & 6.12. & 70 \\
\hline 10. & 7.12 & 76 \\
\hline \multicolumn{2}{|c|}{ Average } & 73,4 \\
\hline
\end{tabular}

The value rather approached $70 \%$ during most of the monitored days. The average value of the hourly stability during the monitored period is $73.4 \%$. This can be regarded as totally inadequate.

A secondary analysis, which evaluated the individual parts of the work shift, was conducted on the basis of this survey. After the comparison of the results of all the monitored days, it was discovered that the largest fluctuations had usually occurred in the first two hours of the shift. During this time, the workers using the machine showed the largest deviations from the desired - planned values. A follow-up analysis of the non-conforming products was performed afterwards, and it has revealed that they did not occur at the end of the shift, when the workers tried to make up for the lost time. The inefficiency during the first two hours of the shift was caused by the fact that there were no managers (foreman) present at the workplace at that time. This was due to the fact that the company had switched to a five-shift operation and it was not possible to secure sufficient number of foreman at the workplace in certain time of the working day.

The higher occurrence of non-conforming products, however, had been the impetus for tracking the hourly output, which eventually revealed the concrete cause. Considering the huge requirements of companies in the automotive industry, the possible long-term solution to the issues related to non-conforming production could have a major impact.

\section{Conclusions}

The analysis of hourly stability of the performance of a worker (machine) can provide key information for production management. It is often very difficult to identify the cause of the problem without a detailed and exact analysis. The fluctuations in the performance of a worker during a work shift can have many negative consequences.

The crucial factors include the high occurrence of low-quality production, which is primarily the result of the fact that if a worker works slower during certain part of his shift, he tries to compensate for the performance reserve later. Increased performance over a short period of time logically brings lack of attention resulting in lowquality work (non-conforming products). The research carried out in the company engaged in manufacturing parts for the automotive industry has clearly demonstrated this fact. The increased amount of low-quality production has unambiguously been influenced by large fluctuations during the work shift.

The hourly stability as a fundamental tool of lean manufacturing enables simple identification and elimination of these problems. In the current highly competitive environment, it is always better to use and preventively apply the tools helping us to prevent any problems. An appropriate and timely performed preventive action is always cheaper than the subsequent solution of generally expensive problems.

\section{References}

[1] BAZALA, J. et al.: Logistika v praxi. Praha: Verlag Dashöfer, 2004. (Original in Czech) 
[2] DAVIS, J. W.: Lean manufacturing: implementation strategies that work: a roadmap to quick and lasting success. Industrial Press Inc., 2009.

[3] HAVERLAND, J., HULA, L., BESTA, P.: Elementární metody klasifikace zásob. In Receseekonomika-technologie. Ostrava: Vysoká škola báňská - Technická univerzita Ostrava, 2010, p. 2227. (Original in Czech)

[4] CHANDRA, CH., GRABIS, J.: Supply chain configuration: concepts, solutions and applications. Springer, 2007.

[5] KOŠTURIAK, J.: Inovace - Vaše konkureční výhoda. Praha: Computer Press, s.r.o., 2008. (Original in Czech)

[6] BESTA, P.; HULA, L.; ŠVAJDOVÁ, L.: Optimalizace nákupního procesu v průmyslovém podniku. In: Inovace a zlepšování v podmínkách ekonomické krize. Ostrava: Vysoká škola báňská Technická univerzita Ostrava, 2011, p. 4-7. (Original in Czech)

[7] PERNICA, P.: Logistika pro 21. století, 2. díl. Praha: Radix, s.r.o., 2005. (Original in Czech)

[8] PERNICA, P.: Logistika pro 21. století, 3. díl. Praha: Radix, s.r.o., 2005. (Original in Czech)

[9] SZABO, S., FERENCZ, V., PUCIHAR, A.: Trust, Innovation and Prosperity. In Quality Innovation Prosperity / Kvalita Inovácia Prosperita. Vol. XVII, No.2, p. 1-8, 2013.

[10] WILSON, L.: How to implement Lean Manufacturing. McGrawHill Professional, 2009.

[11] PERINIĆ M., IKONNIĆ M., MARIČIĆ I.: Die casting process assessment using single minute Exchange of diees (SMED) method. Metalurgija, Vol. 48, No.3, 2009, pp. 199-202.

[12] LENORT, R., BESTA, P.: Logistics of End of Life Electronics Equipment Disassembly. Acta Montanistica Slovaca. 2009, Vol. 14, No. 3, pp. 268274.

[13] MONCZKA, R, M.; HANDFIELD, R., B.; GIUNIPERO, L.: Purchasing and Supply Chain Management. Cengage Learning, 2008.

\section{Review process}

Single-blind peer reviewed process by two reviewers. 